\title{
Availability to pigs of amino acids in cereal grains
}

\section{Factors influencing the availability of amino acids and energy in grains}

\author{
BY M. R. TAVERNER*, AND D. J. FARRELL \\ Department of Biochemistry and Nutrition, University of New England, Armidale, \\ NSW 2351, Australia
}

(Received 29 October 1979 - Accepted 28 February 1980)

\begin{abstract}
1. Protein digestibility and lysint: availability were determined in a range of grain samples using an in vitro digestibility assay calibrated with ileal digestibility values.

2. Mean ( $\pm \mathrm{SE}$ ) values predicted lor nitrogen digestibility were $0.92 \pm 0.011$ in wheat and $0.88 \pm 0.021$ in barley. and the predicted lysine availability in wheat was $0.86 \pm 0.021$.

3. Chemical and physical characteristics of the grains were determined and those most closely associated with protein digestibility for wheat were the contents of hemicellulose, neutral-detergent fibre, the bulk density, and to a lesser extent, $\mathbf{N}$ and acid-dete:-gent fibre contents. These relationships were used to determine prediction equations for the available lysine content of wheat.
\end{abstract}

The availability of lysine in wheat was found by Taverner $e t$ al. (1981 b) to vary from 0.71 to 0.89 for pigs. This range is more than twice that found in protein digestibility values. Sarwar \& Bowland (1975) reported similar differences in lysine availability among wheats which appeared to be respoinsible for differences in growth response of rats given diets containing the wheats and soy'a-bean meal. Certainly as nutrient requirements become more clearly defined the need increases for information regarding variation in nutritive value of wheats, particularly variation in lysine availability.

Eggum (1973) has reported a positive relationship between the content and true digestibility of protein in barley. Similarly with wheat, Taverner et al. $(1981 b)$ found that lysine availability and protein content appeared to be positively related. Eggum \& Christensen (1975) showed that tannin content has a deleterious effect on protein digestibility in barley. Although less tannin occurs in wheat it may be that factors other than protein content are alsc related to protein availability.

Drennan \& Maguire (1970) and King \& Taverner (1975) found a close negative correlation of digestible energy (DE) content and fibre content of cereal-based diets for pigs. Similarly with poultry, Salmon \& O'Neil (1977) and Moir \& Connor (1977) showed that metabolizable energy (ME) in 'wheat and sorghum respectively, was negatively correlated to fibre content. Clearly, the concentration of fibre and lysine in the outer layers of the wheat grain suggest that fibre content may also be a factor affecting protein digestibility and amino acid availability in wheat. Unfortunately, there is no published evidence relating fibre and amino acid availability in grains.

The aims of the present experiment were to determine : $(a)$ the range of protein digestibility and lysine availability values that exists among a large number of Australian wheats and also of protein digestibility in a smaller but representative sample of Australian barleys: (b) the relationship of these values to various chemical and physical characteristics of the grains, including the content of total nitrogen, acid-(ADF) and neutral-(NDF) detergent fibre, hemicellulose, albumin plus globulin- $\mathrm{N}$ and the bulk density of the grains; $(c)$ the effects of wheat variety and growth environment (locality) on protein digestibility, lysine availability, protein content, fibre content and bulk density; (d) the relationship between the DE content of wheats and some of their chemical and physical characteristics.

\footnotetext{
- Present address: Animal Research Institute, Werribee, Victoria 3030. Australia.
} 
Table 1. Grain varieties, their predicted values of $N$ digestibility and lysine availability, contents of $N$, neutral (NDF)- and acid $(A D F)$-detergent fibres and hemicellulose and bulk density

\begin{tabular}{|c|c|c|c|c|c|c|c|c|c|}
\hline \multirow{2}{*}{$\begin{array}{l}\text { Grain } \\
\text { variety }\end{array}$} & \multirow{2}{*}{$\begin{array}{c}\text { Locality } \\
\text { no. }\end{array}$} & \multirow{2}{*}{ Sample } & \multirow{2}{*}{$\begin{array}{c}\mathbf{N} \\
\text { digestibility }\end{array}$} & \multirow{2}{*}{$\begin{array}{c}\text { Lysine } \\
\text { availability }\end{array}$} & \multirow{2}{*}{$\begin{array}{c}\text { Bulk } \\
\text { density } \\
(\mathrm{kg} / \mathrm{hl})\end{array}$} & \multicolumn{4}{|c|}{ Composition (g/kg DM) } \\
\hline & & & & & & $\mathbf{N}$ & NDF & $\mathrm{ADF}$ & Hemicellulose \\
\hline \multirow[t]{4}{*}{ Wheat: } & 1 & $\mathbf{A}$ & 0.92 & 0.89 & NA & 24.9 & 118 & 42 & 76 \\
\hline & 2 & B & 0.91 & 0.83 & NA & $23 \cdot 8$ & 115 & 38 & 77 \\
\hline & 3 & $\mathrm{C}$ & 0.87 & 0.79 & NA & $19 \cdot 2$ & 158 & 41 & 117 \\
\hline & 5 & $\mathbf{D}$ & 0.92 & 0.86 & NA & $22 \cdot 2$ & 114 & 40 & 74 \\
\hline Condor & & 1 & 0.95 & 0.92 & 83 & $22 \cdot 3$ & 78 & 35 & 43 \\
\hline Eagle & & 2 & 0.93 & 0.89 & 78 & $25 \cdot 2$ & 104 & 40 & 64 \\
\hline Egret & & 3 & 0.92 & 0.88 & 82 & $20 \cdot 3$ & 83 & 32 & 51 \\
\hline Gamut & & 4 & 0.93 & 0.88 & 79 & 19.9 & 108 & 38 & 70 \\
\hline Gatcher & & 5 & 0.93 & 0.89 & 82 & $21 \cdot 2$ & 100 & 35 & 65 \\
\hline Teal & & 6 & 0.93 & 0.88 & 79 & $19 \cdot 8$ & 95 & 33 & 62 \\
\hline Timgalen & & 7 & 0.92 & 0.87 & 82 & $24 \cdot 6$ & 121 & 38 & 83 \\
\hline Timgalen & & 8 & 0.92 & 0.86 & 73 & $31 \cdot 1$ & 121 & 41 & 80 \\
\hline \multirow[t]{3}{*}{ Oxley: } & 1 & 9 & 0.90 & 0.82 & 75 & $27 \cdot 5$ & 154 & 41 & 113 \\
\hline & 2 & 10 & 0.91 & 0.85 & 82 & $24 \cdot 1$ & 135 & 37 & 98 \\
\hline & 3 & 11 & 0.91 & 0.86 & 82 & $25 \cdot 7$ & 136 & 33 & 103 \\
\hline \multirow[t]{3}{*}{ Olympic: } & 1 & 12 & 0.90 & 0.84 & 76 & $24 \cdot 4$ & 108 & 37 & 71 \\
\hline & 2 & 13 & 0.91 & 0.86 & 76 & $27 \cdot 3$ & 94 & 33 & 61 \\
\hline & 3 & 14 & 0.91 & 0.86 & 82 & $22 \cdot 2$ & 95 & 31 & 64 \\
\hline \multirow[t]{3}{*}{ Summit: } & 1 & 15 & 0.91 & 0.85 & 78 & $23 \cdot 1$ & 110 & 36 & 74 \\
\hline & 2 & 16 & 0.92 & 0.87 & 81 & $25 \cdot 3$ & 102 & 32 & 70 \\
\hline & 3 & 17 & 0.92 & 0.88 & 84 & 21.9 & 96 & 31 & 65 \\
\hline \multirow[t]{3}{*}{ Condor: } & 1 & 18 & 0.91 & 0.85 & 80 & $25 \cdot 2$ & 137 & 39 & 98 \\
\hline & 2 & 19 & 0.93 & 0.89 & 81 & 26.9 & 143 & 37 & 106 \\
\hline & 3 & 20 & 0.92 & 0.87 & 84 & 23.9 & 137 & 33 & 104 \\
\hline \multirow[t]{3}{*}{ Insignia: } & 1 & 21 & 0.89 & 0.81 & 78 & $23 \cdot 7$ & 127 & 35 & 92 \\
\hline & 2 & 22 & 0.91 & 0.86 & 79 & 26.9 & 123 & 35 & 88 \\
\hline & 3 & 23 & 0.91 & 0.86 & 83 & $23 \cdot 1$ & 107 & 32 & 75 \\
\hline \multirow[t]{3}{*}{ Egret: } & 1 & 24 & 0.91 & 0.85 & 79 & $22 \cdot 6$ & 115 & 36 & 79 \\
\hline & 2 & 25 & 0.92 & 0.87 & 80 & $26 \cdot 5$ & 107 & 35 & 72 \\
\hline & 3 & 26 & 0.91 & 0.85 & 84 & $22 \cdot 6$ & 102 & 30 & 72 \\
\hline \multirow[t]{3}{*}{ Emblem: } & 1 & 27 & 0.92 & 0.87 & 77 & $24 \cdot 6$ & 113 & 36 & 77 \\
\hline & 2 & 28 & 0.92 & 0.87 & 81 & $24 \cdot 2$ & 97 & 31 & 66 \\
\hline & 3 & 29 & 0.92 & 0.87 & 84 & $20 \cdot 0$ & 111 & 27 & 84 \\
\hline \multirow[t]{5}{*}{ Egret: } & 1 & 30 & 0.92 & 0.88 & 85 & $20 \cdot 5$ & 89 & 29 & 60 \\
\hline & 2 & 31 & 0.91 & 0.85 & 82 & $18 \cdot 3$ & 94 & 29 & 65 \\
\hline & $\overline{3}$ & 32 & 0.93 & 0.89 & 83 & $14 \cdot 5$ & 89 & 29 & 60 \\
\hline & 4 & 33 & 0.91 & 0.86 & 82 & $26 \cdot 1$ & 101 & 30 & 71 \\
\hline & 5 & 34 & 0.90 & 0.84 & 75 & $27 \cdot 2$ & 108 & 37 & 71 \\
\hline \multirow[t]{5}{*}{ Cook: } & 1 & 35 & 0.92 & 0.87 & 85 & $24 \cdot 5$ & 110 & 33 & 77 \\
\hline & 2 & 36 & 0.92 & 0.86 & 85 & $20 \cdot 2$ & 115 & 31 & 84 \\
\hline & 3 & 37 & 0.93 & 0.89 & 87 & $17 \cdot 3$ & 98 & 32 & 66 \\
\hline & 4 & 38 & 0.91 & 0.86 & 84 & $29 \cdot 3$ & 101 & 34 & 67 \\
\hline & 5 & 39 & 0.91 & 0.86 & 79 & $31 \cdot 1$ & 115 & 36 & 79 \\
\hline Shortim & & 40 & 0.90 & 0.84 & 77 & $32 \cdot 7$ & 114 & 40 & 74 \\
\hline Gamenya & & 41 & 0.90 & 0.83 & 75 & $28 \cdot 7$ & 129 & 43 & 86 \\
\hline Halberd & & 42 & 0.91 & 0.86 & 79 & $31 \cdot 8$ & 121 & 35 & 86 \\
\hline Oxley & & 43 & 0.92 & 0.87 & 75 & 29.9 & 143 & 39 & 104 \\
\hline Eagle & & 44 & 0.94 & 0.90 & 78 & $28 \cdot 7$ & 126 & 43 & 83 \\
\hline Tincurrin & & 45 & 0.90 & 0.84 & 75 & $24 \cdot 4$ & 156 & 43 & 113 \\
\hline Eagle & & 46 & 0.92 & 0.88 & 78 & $26 \cdot 1$ & 122 & 43 & 79 \\
\hline Timgalen & & 47 & 0.91 & 0.85 & 73 & $31 \cdot 8$ & 132 & 46 & 86 \\
\hline Wheat no. 4 & & 48 & 0.87 & 0.77 & NA & $18 \cdot 8$ & 160 & 60 & 100 \\
\hline
\end{tabular}




\begin{tabular}{|c|c|c|c|c|c|c|c|c|c|}
\hline \multirow{2}{*}{$\begin{array}{l}\text { Grain } \\
\text { variety }\end{array}$} & \multirow{2}{*}{$\begin{array}{c}\text { Locality } \\
\text { no. }\end{array}$} & \multirow[b]{2}{*}{ Sample } & \multirow{2}{*}{$\underset{\text { digestibility }}{\mathrm{N}}$} & \multirow{2}{*}{$\begin{array}{c}\text { Lysine } \\
\text { availability }\end{array}$} & \multirow{2}{*}{$\begin{array}{c}\text { Bulk } \\
\text { density } \\
(\mathbf{k g} / \mathrm{hl})\end{array}$} & \multicolumn{4}{|c|}{ Composition (g/kg DM) } \\
\hline & & & & & & $\mathbf{N}$ & NDF & $\mathrm{ADF}$ & Hemicellulose \\
\hline \multicolumn{10}{|l|}{ Barley } \\
\hline Barley & & $\mathbf{E}$ & 0.84 & 0.84 & NA & $21 \cdot 2$ & 163 & 72 & 91 \\
\hline Abyssinian & & 49 & 0.91 & ND & 64 & $15 \cdot 8$ & 188 & 96 & 92 \\
\hline Beecher & & 50 & 0.86 & ND & 63 & 13.8 & 185 & 91 & 94 \\
\hline Clipper & & 51 & 0.91 & ND & 70 & 20.2 & 148 & 75 & 73 \\
\hline Clipper & & 52 & 0.88 & ND & 69 & 17.8 & 158 & 64 & 94 \\
\hline Lara & & 53 & 0.89 & ND & 64 & $14 \cdot 2$ & 161 & 77 & 84 \\
\hline Resibee & & 54 & 0.89 & ND & 71 & $13 \cdot 2$ & 175 & 70 & 105 \\
\hline Weeah & & 55 & 0.82 & ND & 61 & 10.8 & 195 & 76 & 119 \\
\hline New & & 56 & 0.88 & ND & 61 & $17 \cdot 7$ & 164 & 82 & 82 \\
\hline
\end{tabular}

NA, not available; ND, not determined.

\section{EXPERIMENTAL PROCEDURES}

\section{Grain samples}

A total of fifty-two wheat and nine barley samples was analysed. The grain samples are listed in Table 1.

Samples A, B, C, D and E were grains from previous work (Taverner et al. $1981 \mathrm{~b}$ ) from which their in vivo digestibility values for $\mathrm{N}$ and lysine were available. These were used to determine standard linear relationships with in vitro digestibility values. Samples nos. 1-8, and 49 were provided by Dr E. S. Batterham, Agricultural Research Centre, Wollongbar, New South Wales. They were selected from various areas of Eastern Australia as representative samples of wheat and barley. Samples nos. 9-29 were provided by the Victorian Department of Agriculture; grain from each of seven varieties was grown in central (locality 1 , Werribee), north-eastern (locality 2, Rutherglen) and western (locality 3, Longerenong) Victoria. Samples nos. 30-47 were provided by Mr J. A. Fisher, Agricultural Research Institute, Wagga Wagga, New South Wales and included samples from two varieties grown in southern New South Wales either under irrigation at Wagga, Leeton, and Yanco (localities 1, 2 and 3 respectively) or under dryland conditions at Collingullie and Wagga (localities 4 and 5). Sample no. 48 was wheat no. 4 in the previous experiment for which in vivo values were unsatisfactory (Taverner $e t$ al. 1981 b).

The wheat cultivars covered a wide range of grain hardness. The barley cultivars included both six-row types (samples nos. 49 and 50 ) and two-row types.

\section{F'hysical and chemical analyses}

Values for bulk density and DE of grains for samples nos. 1-8 and 49-56, and lysine content of samples nos. 1-8 were provided by Dr E. S. Batterham and are shown in Table 2. The weight of a specific volume $(50 \mathrm{ml}$ in a cylindrical container) of whole grain (lab weight) was measured for each wheat sample and bulk density values were estimated by interpolation from a linear relationship of bulk density $(\mathrm{kg} / \mathrm{hl})$ on lab weight established with samples nos. 1-8.

Representative subsamples of each grain were milled to pass first through a $2 \mathrm{~mm}$ screen and then through a $1 \mathrm{~mm}$ screen. The contents of moisture, N, ADF and albumin plus globulin were determined using methods previously described (Taverner $e t$ al. $1981 a, b$ ). 
Table 2. The contents of digestible energy (DE), lysine and albumin plus globulin-nitrogen for thirteen samples of wheat (DM) basis

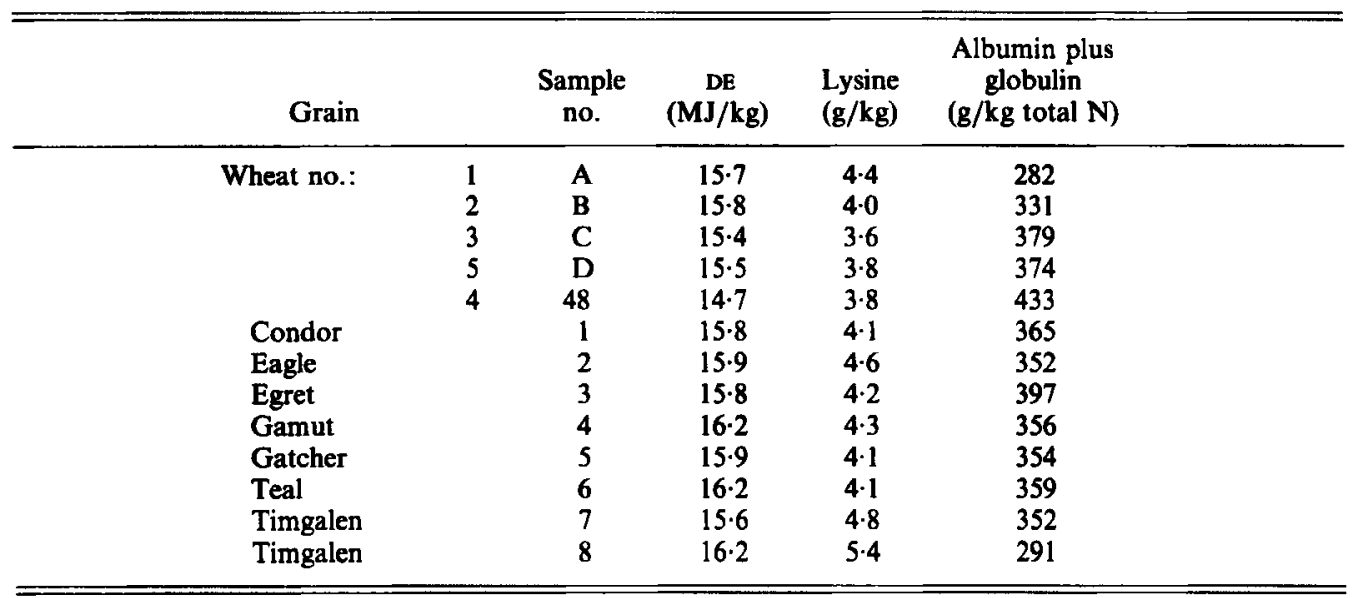

† Values for samples nos. 1-8 were provided by Dr E. S. Batterham, Agricultural Research Centre, Wollongbar, New South Wales.

NDF content of all grains was measured by the modified (amylase treatment) method described by Taverner $e t a l$. $(1981 b)$. Hemicellulose was calculated as the diference between $\mathrm{ADF}$ and NDF values.

\section{In vitro $N$ digestibility}

The in vitro protein digestibility of each grain was determined in duplicate with pronase (Taverner \& Farrell 1981). Three different batches of pronase (B grade; Calbiochem) were used. The standard wheats, samples A, B, C, D, were assayed using each batch of enzyme and sample $\mathrm{E}$ (barley) was included with these in the third assay. Using these values, linear regressions of in vitro on in vivo values of $\mathbf{N}$ digestibility were determined for each assay, and for the first two assays linear regressions of in vitro $\mathrm{N}$ digestibility on in vivo lysine availability were determined. Samples nos. 1-8, 9-48, and 49-56 were assayed with separate batches of pronase; $\mathbf{N}$ digestibility and lysine availability were predicted from the appropriate standard line.

\section{Statistical methods}

Canonical correlation methods described by Taverner \& Farrell (1981) were used to estimate linear combinations of grain composition factors which correlated maximally with protein digestibility, lysine availability or DE content. The analysis provided the correlation of each grain composition variate with each other variate, the correlation of each composition variate with protein digestibility, lysine availability or $\mathrm{DE}$, and the correlation of each canonical score with the original variates.

The BAR3 and NEVA programs developed at the University of New England Computer Centre by Professor E. J. Burr were used for linear regression analyses and analyses of variance respectively. 
Table 3. Standard relationships of in vivo $N$ digestibility and lysine availability $(\mathrm{Y})$ on in vitro $N$ digestibility $(\mathrm{X})$ for each pronase assay

\begin{tabular}{cccc}
\hline \hline $\begin{array}{c}\text { Pronase } \\
\text { assay }\end{array}$ & $\begin{array}{c}\text { N } \\
\text { digestibility }\end{array}$ & $\begin{array}{c}\text { Statistical } \\
\text { significance } \\
\text { of regression } \\
\text { coefficient }\end{array}$ & $R^{2}$ \\
\hline 1 & $Y=47.78+0.49( \pm 0.068) X$ & $* * *$ & 0.79 \\
2 & $Y=41.85+0.54( \pm 0.089) X$ & $* * *$ & 0.86 \\
3 & $Y=26 \cdot 44+0.72( \pm 0.109) X$ & $* * *$ & 0.85 \\
& Lysine availability & $* * *$ & 0.84 \\
1 & $Y=3 \cdot 59+0.93( \pm 0.109) X$ & $* * *$ & 0.96 \\
\hline
\end{tabular}

$$
\text { *** } P<0.001 \text {. }
$$

Table 4. The average values of $N$, neutral (NDF)- and acid (ADF)-detergent fibres and hemicellulose contents and the lulk density for forty-seven samples of wheat and the pairwise correlation coefficients of the variables

\begin{tabular}{lccccc}
\hline \hline & $\begin{array}{c}N \\
(\mathrm{mg} / \mathrm{g})\end{array}$ & $\begin{array}{c}\mathrm{NDF} \\
(\mathrm{g} / \mathrm{kg})\end{array}$ & $\begin{array}{c}\mathrm{ADF} \\
(\mathrm{g} / \mathrm{kg})\end{array}$ & $\begin{array}{c}\text { Hemicellulose } \\
(\mathrm{g} / \mathrm{kg})\end{array}$ & $\begin{array}{c}\text { Bulk density } \\
(\mathrm{kg} / \mathrm{hl})\end{array}$ \\
\hline N & $1.00^{*}$ & & & & \\
NDF & 0.48 & 1.00 & & & \\
ADF & 0.61 & 0.61 & 1.00 & & \\
Hemicellulose & 0.38 & 0.96 & 0.43 & 1.00 & 1.00 \\
Bulk density & -0.60 & -0.45 & -0.75 & -0.30 & 80.0 \\
Mean & 24.7 & 113 & 35 & 78 & 3.50 \\
$\quad$ SD & 4.01 & 18.2 & 4.4 & 15.8 & \\
\hline \hline
\end{tabular}

- Correlation coefficients at $P<0.05$ and $P<0.010 .288$ and 0.372 respectively.

\section{RESULTS}

Prediction equations. For each batch of pronase, in vitro and in vivo values were linearly related $(P<0.001)$. The relationships between in vitro $\mathbf{N}$ digestibility and in vivo $\mathbf{N}$ digestibility and lysine availability for each of the three pronases are presented in Table 3.

Grain composition. The cortents of N, NDF, ADF, and hemicellulose are presented for each grain in Table 1. Estimates of bulk density are also included.

The wheat contained ( $/ \mathrm{g}$; mean $\pm \mathrm{SD}): 24.7 \pm 4.01 \mathrm{mg} \mathrm{N}, 113 \pm 18.2 \mathrm{mg} \mathrm{NDF}, 35 \pm 4.4 \mathrm{mg}$ ADF, $78 \pm 15.8 \mathrm{mg}$ hemicellulose and had a bulk density of $80 \pm 3.5 \mathrm{~kg} / \mathrm{hl}$. For the thirteen wheats for which values of DE and albumin plus globulin contents were determined (Table 2), the mean ( $\pm \mathrm{SD}$ ) values were $15 \cdot 7 \pm 0.41 \mathrm{MJ} / \mathrm{kg}$ and $35 \cdot 6 \pm 3.97 \%$ of the total protein respectively.

The mean $( \pm \mathrm{SD})$ values for the eight barley samples were $(/ \mathrm{g}): 15.4 \pm 3.03 \mathrm{mg} \mathrm{N}$, $172 \pm 16.6 \mathrm{mg}$ NDF, $79 \pm 10.5 \mathrm{mg}$ ADF, $93 \pm 14.3 \mathrm{mg}$ hemicellulose and bulk density 65 $( \pm 4 \cdot 0) \mathrm{kg} / \mathrm{hl}$.

The correlation coeffieicent: between these factors are presented in Table 4 for wheat and Table 5 for barley. There wats a significant $(P<0.05)$ negative correlation between the $\mathbf{N}$ content of barley and its hemicellulose content. In contrast, the $\mathbf{N}$ content of wheat 
Table 5. The average values of $N$, neutral $(N D F)$ - and acid $(A D F)$-detergent fibres and hemicellulose contents, bulk density and $N$ digestibility of eight samples of barley and the pairwise correlation coefficients of these values

\begin{tabular}{lcccccc}
\hline \hline & $\begin{array}{c}\mathrm{N} \\
(\mathrm{mg} / \mathrm{g})\end{array}$ & $\begin{array}{c}\text { NDF } \\
(\mathrm{g} / \mathrm{kg})\end{array}$ & $\begin{array}{c}\text { ADF } \\
(\mathrm{g} / \mathrm{kg})\end{array}$ & $\begin{array}{c}\text { Hemicellulose } \\
(\mathrm{g} / \mathrm{kg})\end{array}$ & $\begin{array}{c}\text { Bulk weight } \\
(\mathrm{kg} / \mathrm{hl})\end{array}$ & $\begin{array}{c}\mathrm{N} \\
\text { digestibility }\end{array}$ \\
\hline $\mathrm{N}$ & 1.00 & & & & & \\
NDF & -0.70 & 1.00 & & & & \\
ADF & -0.10 & 0.46 & 1.00 & & & \\
Hemicellulose & $-0.74^{*}$ & 0.68 & -0.12 & 1.00 & & \\
Bulk weight & 0.34 & -0.46 & -0.51 & -0.16 & 1.00 & 1.00 \\
Nitrogen digestibility & 0.62 & -0.50 & 0.09 & -0.65 & 0.46 & 0.88 \\
Mean & 15.4 & 172 & 79 & 93 & 65.4 & 0.029 \\
$\quad$ SD & 3.03 & 16.6 & 6.5 & 14.3 & 4.03 & \\
\hline \hline
\end{tabular}

- Value statististically significant $(P<0.05)$.

Table 6. The relative importance of different parameters of grain composition to the canonical correlation of grain composition and the predicted lysine availability of forty-seven wheat samples

\begin{tabular}{cccc}
\hline $\begin{array}{c}\text { Significance } \\
\text { of canonical } \\
\text { correlation }\end{array}$ & $\begin{array}{c}\text { Original } \\
\text { composition } \\
\text { variate }\end{array}$ & $\begin{array}{c}\text { Correlation of the } \\
\text { original variate with } \\
\text { the canonical variate }\end{array}$ \\
\hline$P<0.001$ & $\begin{array}{l}\text { Hemicellulose } \\
\text { Neutral-detergent } \\
\text { fibre } \\
\text { Bulk density } \\
\text { Nitrogen } \\
\text { Acid-detergent } \\
\text { fibre }\end{array}$ & -0.72 \\
& 0.70 \\
\hline
\end{tabular}

was positively correlated $(P<0.01)$ with all fibre estimates. The bulk density of wheat was negatively correlated $(P<0.01)$ with $\mathrm{N}$ contents $(r-0.60, n 47)$ and with ADF content $(r-0 \cdot 75, n 47)$.

With measurements from thirteen wheats, the proportion of albumin plus globulin in the protein was negatively correlated with protein content $(r-0.71, P<0.01)$. DE was negatively correlated with both NDF $(r-0.62, P<0.05)$ and ADF $(r-0.72, P<0.01)$, and there was a significant $(P<0.05)$ canonical correlation between DE and a canonical variate in which ADF, NDF, hemicellulose and $N$ were all associated with DE. In the above order, the correlations of these variates to the canonical variate were $-0.91-0.79,-0.67$, and $\mathbf{0 . 4 5}$. There was therefore a major association of ADF and DE. This relationship was examined by regression analysis and ADF was found to account for $61 \%$ of the variation in DE $(P<0.001)$. 'DE $(\mathrm{MJ} / \mathrm{kg})=17.54( \pm 0.44)-0.046( \pm 0.011) \mathrm{ADF}(\mathrm{mg} / \mathrm{kg})$.

$N$ digestibility and lysine availability. In vitro digestibility values for most wheats were within the range of values covered by the standard wheats. The predicted values of $\mathbf{N}$ digestibility and lysine availability in all samples are shown in Table 1.

Mean $( \pm S D)$ values for $N$ digestibility and lysine availability in wheat were $0.92 \pm 0.011$ and $0.86 \pm 0.021$ respectively. There were significant canonical correlations $(P<0.001)$ between these factors and the composition factors (Table 6). Hemicellulose, NDF and bulk 
Table 7. The effects of variety and locality on the protein digestibility, lysine availability, bulk density and the contents of $N$, neutral $(N D F)$-and acid $(A D F)$-detergent fibres and hemicellulose of wheats grown in Victoria

\begin{tabular}{|c|c|c|c|c|c|c|c|}
\hline & \multirow{2}{*}{$\begin{array}{c}\text { Protein } \\
\text { digestibility }\end{array}$} & \multirow{2}{*}{$\begin{array}{c}\text { Lysine } \\
\text { availability }\end{array}$} & \multirow{2}{*}{$\begin{array}{c}\text { Bulk } \\
\text { density } \\
\text { (kg/hl) }\end{array}$} & \multicolumn{4}{|c|}{ Grain composition (g/kg DM) } \\
\hline & & & & $\mathbf{N}$ & NDF & ADF & Hemicellulose \\
\hline \multicolumn{8}{|l|}{ Variety } \\
\hline Oxley & 0.91 & 0.84 & $79 \cdot 7$ & 25.8 & $142^{a}$ & $37^{a}$ & $105^{a}$ \\
\hline Olympic & 0.91 & 0.85 & 78.0 & 24.6 & $99^{b}$ & $34^{b}$ & $65^{c}$ \\
\hline Summit & 0.92 & 0.87 & $81 \cdot 0$ & $23 \cdot 4$ & $103^{b}$ & $33^{b c}$ & $70^{c}$ \\
\hline Condor & 0.92 & 0.87 & 81.7 & $25 \cdot 3$ & $139^{a}$ & $36^{a}$ & $103^{\alpha}$ \\
\hline Insignia & 0.90 & 0.84 & $80 \cdot 0$ & $24 \cdot 6$ & $119^{b}$ & $34^{b}$ & $85^{b}$ \\
\hline Egret & 0.91 & 0.86 & $81 \cdot 0$ & $23 \cdot 9$ & $108^{b}$ & $34^{b}$ & $74^{b c}$ \\
\hline Emblem & 0.92 & 0.87 & $80 \cdot 7$ & $22 \cdot 9$ & $107^{b}$ & $31^{c}$ & $76^{b c}$ \\
\hline SEM & 0.004 & 0.007 & 0.76 & 0.9 & 3.4 & 0.7 & $3 \cdot 5$ \\
\hline Significance level & NS & NS & NS & NS & $* * *$ & $* * *$ & $* * *$ \\
\hline \multicolumn{8}{|l|}{ Locality no. } \\
\hline 1 (Werribee) & $0.90^{a}$ & $0.84^{a}$ & $77 \cdot 6^{a}$ & $24 \cdot 4^{a b}$ & $123^{a}$ & $37^{a}$ & 86 \\
\hline 2 (Rutherglen) & $0.92^{b}$ & $0.87^{b}$ & $80 \cdot 0^{6}$ & $25 \cdot 9^{a}$ & $114^{b}$ & $34^{b}$ & 80 \\
\hline 3 (Longerenong) & $0.92^{b}$ & $0.86^{b}$ & $83 \cdot 3^{c}$ & $22 \cdot 8^{b}$ & $112^{b}$ & $31^{c}$ & 81 \\
\hline SEM & 0.002 & 0.005 & 0.50 & 0.6 & $2 \cdot 3$ & 0.5 & $2 \cdot 3$ \\
\hline Significance level & $* *$ & ** & $* * *$ & $* *$ & $* *$ & ** & NS \\
\hline
\end{tabular}

NS, not significant.

$a, b, c$, Within columns, means followed by different superscripts were significantly different $(P<0.05)$.

$* * P<0.001, \quad * * * P<0.0005$.

density were the components most associated with $\mathrm{N}$ digestibility and lysine availability; $\mathbf{N}$ and ADF contents were less important. The digestibility of $\mathbf{N}$ in wheat was not significantly correlated with albumin plus globulin content $(r$ 0.40, $n$ 13) but it was significantly correlated with DE content $(r 0.69, n 13, P<0.01)$.

The digestibility of $\mathrm{N}$ in barley was $0.88 \pm 0.021$ but $\mathrm{N}$ digestibility was not significantly correlated with the contents of hemicellulose $(r-0.65), \mathrm{N}(r 0.62)$, NDF $(r-0.50)$ or ADF ( $r$ 0.09).

Effects of wheat variety and locality. The effects of wheat variety and locality (growth environment) on $\mathrm{N}$ digestibility, lysine availability and the composition factors were assessed using grains from seven varieties grown at three localities in Victoria (Table 7) and from two varieties grown at five localities in New South Wales (Table 8).

Although the predicted values of $\mathbf{N}$ digestibility and lysine availability were not independent, both values are presented to indicate the extent of variation expected for these effects. In both instances, locality but not variety had a significant effect on the predicted values.

Similarly, the $\mathbf{N}$ content and bulk density of Victorian wheats (Table 7) were affected by locality $(P<0.01)$ but not variety. The N content of New South Wales wheats (Table 8) varied significantly $(P<0.001)$ between localities from 15.9 to $29.2 \mathrm{mg} / \mathrm{g}$. Wheats grown under dryland conditions (locsalities 4 and 5$)$ had higher $N$ contents $(P<0.01)$ than those grown under irrigation. However, wheat variety also affected $(P<0.01) \mathrm{N}$ content.

The ADF and NDF conterts of Victorian wheats were influenced by variety $(P<0.001)$ and locality $(P<0.01)$, but these effects were smaller for New South Wales wheats. 
Table 8. The effects of variety and locality on the protein digestibility, lysine availability, bulk density and the contents of $N$, neutral $(N D F)$-and acid $(A D F)$-detergent fibres and hemicellulose of wheat grown in New South Wales

\begin{tabular}{|c|c|c|c|c|c|c|c|}
\hline & \multirow{2}{*}{$\begin{array}{c}\text { Protein } \\
\text { digestibility }\end{array}$} & \multirow{2}{*}{$\begin{array}{c}\text { Lysine } \\
\text { availability }\end{array}$} & \multirow{2}{*}{$\begin{array}{c}\text { Bulk } \\
\text { density } \\
\text { (kg/hl) }\end{array}$} & \multicolumn{4}{|c|}{ Grain composition (g/kg DM) } \\
\hline & & & & $\mathbf{N}$ & NDF & $\mathrm{ADF}$ & Hemicellulose \\
\hline \multicolumn{8}{|l|}{ Variety } \\
\hline Egret & 0.92 & 0.86 & $81 \cdot 4^{a} \dagger$ & $21 \cdot 3^{a}$ & $96^{a}$ & 31 & 65 \\
\hline Cook & 0.92 & 0.87 & $84 \cdot 0^{b}$ & $24 \cdot 5^{b}$ & $108^{b}$ & 33 & 75 \\
\hline SEM & 0.002 & 0.003 & 0.53 & 0.3 & 2.9 & 0.7 & $2 \cdot 9$ \\
\hline Significance level & NS & NS & $*$ & $* *$ & $*$ & NS & NS \\
\hline \multicolumn{8}{|l|}{ Locality no.† } \\
\hline 1 (Wagga) & $0.92^{a b}$ & $0.88^{a b}$ & $85 \cdot 0^{a}$ & $22 \cdot 5^{a}$ & 100 & $31^{a}$ & 69 \\
\hline 2 (Leeton) & $0.91^{b}$ & $0.86^{b c}$ & $83 \cdot 5^{a}$ & $19 \cdot 3^{b}$ & 105 & $30^{a}$ & 75 \\
\hline 3 (Yanco) & $0.93^{a}$ & $0.89^{a}$ & $85 \cdot 0^{a}$ & $15.9^{c}$ & 94 & $31^{a}$ & 63 \\
\hline 4 (Collingullie) & $0.91^{b}$ & $0.86^{b c}$ & $83 \cdot 0^{a}$ & $27 \cdot 7^{d}$ & 101 & $32^{a}$ & 69 \\
\hline 5 (Wagga) & $0.91^{c}$ & $0.85^{c}$ & $77 \cdot 0^{b}$ & $29 \cdot 2^{d}$ & 112 & $37^{b}$ & 75 \\
\hline SEM & 0.003 & 0.005 & 0.84 & 0.4 & $4 \cdot 6$ & 1.0 & $4 \cdot 6$ \\
\hline Significance level & $*$ & $*$ & $*$ & $m * *$ & NS & $*$ & NS \\
\hline
\end{tabular}

NS, not significant.

$a, b, c$, Within columns, means followed by different superscripts were significantly different $(P<0.05)$.

* $P<0.01, \quad$ ** $P<0.005, \quad * * * P<0.001$.

$\dagger$ Localities 1, 2 and 3 were irrigated and 4 and 5 were dryland crops.

\section{DISCUSSION}

\section{The pronase assay}

Pronase was used by Saunders \& Kohler (1972) and Miladi et al. (1972) to determine protein digestibility in wheat and wheat by-products. As in the present experiment, they found that in vitro digestibility values of protein were closely related to in vivo values. Rayner \& Fox $(1976,1978)$ found that pronase was also effective in releasing amino acids from rapeseed meal and beef muscle, and that the amount of lysine released was related to the amount of chemically reactive lysine. In the present study, grains of known true ileal digestibility of $\mathbf{N}$ and availability of amino acids were used as reference standards.

$\mathrm{N}$ digestibility and lysine availability, which were shown by Taverner $e t$ al. $(1981 b)$ to be significantly correlated $(r 0.77, P<0.01)$, were both predicted from in vitro $\mathrm{N}$ digestibility values. With the close relationship between ileal lysine availability and in vitro $\mathrm{N}$ digestibility, it seemed unnecessary to determine in vitro lysine availability. However, because both were predicted from relationships established with the same in vitro values, the predicted values of $\mathbf{N}$ digestibility and lysine availability are not independent. Relationships can also be determined to predict the true availability of other amino acids that were found in the previous experiment to be closely correlated with $\mathbf{N}$ digestibility. For example, true ileal availability values for threonine were significantly correlated $(P<0.01)$ with the in vitro $\mathrm{N}$ digestibility values for wheat. From such relationships mean $( \pm$ SE) availability values can be predicted, for instance, $0.88 \pm 0.015$ for threonine in wheat, but they provide no further information on factors that might specifically influence availability of individual amino acids.

There was a difference between assays in the extent to which $\mathbf{N}$ was released by pronase. Consequently, the in vitro values were of little meaning by themselves as relative indices 
of digestibility and rely on calibration using standard relationships with values that are biologically meaningful. For example, there would be little value in using chemically reactive lysine values to calibrate in vitro digestibility values for grains, as Rayner \& Fox (1976, 1978) have done for rapeseed meal and meat, since reactive-lysine content is not necessarily related to available lysine content of cereals (Taverner \& Farrell 1981). Saunders \& Kohler (1972) related in vitro $\mathbf{N}$ digestibility and faecal $\mathrm{N}$ digestibility. Miladi et al. (1972), using the same method, calculated lysine and threonine availabilities by assuming that the biological availability of these amino acids was limited to the same extent as the in vitro $\mathrm{N}$ digestibility. The weakness in this assumption was shown by Taverner $e t$ al. $(1981 \mathrm{~b})$ who found the availability of both lysine and threonine were found to be substantially less than $\mathrm{N}$ digestibility. Clearly, as Mauron (1970) has discussed, the utility of an in vitro assay such as the present pronase assay in predicting amino acid availability depends to a large extent on the availability of standard materials and relevant availability values.

\section{Grain composition}

The characteristics of grain composition that are generally considered to be important by the wheat industry are those which fit the grain for bread-making. Of the wheat proteins for example, the gliadin and glutenin fractions have received most emphasis because of their importance in dough formation, but these fractions are nutritionally inferior to the albumin and globulin fractions which contain a higher proportion of lysine. Another characteristic of wheat that is important both for milling and for animal nutrition is the proportion of bran to endosperm. Several techniques have been used to predict this value. These include manual dissection of grains, insect feeding assays and chemical assays such as the NDF technique of Van Soest \& Wine (1967). Moss \& Stenvert (1971) and Stenvert \& Moss (1974) found that the fibre separated by the latter method contained no endosperm material and varied from 105 to $185 \mathrm{mg} / \mathrm{g}$ grain for a range of wheat cultivars. They found that fibre content was closely and negatively correlated to the flour-yielding potential of both soft and hard wheats.

The main constituents of the fibre residue after neutral-detergent treatment are plant cell wall substances including cellulose, hemicellulose and lignin. In the present experiment, the majority of NDF in wheat w.1s hemicellulose (69\%). Similarly, Fraser \& Holmes (1959) found that hemicelluloses were the most abundant carbohydrate in wheat bran, to which they contributed $43 \%$ and cellulose $35 \%$ of the total carbohydrate.

For the forty-seven wheats included in the in vitro studies in the present experiment, NDF, ADF and hemicellulose contents were positively correlated with $\mathrm{N}$ content and negatively correlated with bulk density (Table 4). But these relationships are not consistent for all wheats and for the separate aralysis of thirteen wheats in this experiment and the analyses of March \& Biely (1973) and Salmon \& O'Neil (1977), there was no significant correlation of $\mathbf{N}$ and fibre content in wheat.

\section{The relationship between grain composition and nutrient availability}

For both wheat and barley, hemicellulose was the component most closely associated with protein digestibility and amino acid availability. NDF, of which hemicellulose is the major component, was also related tc protein digestibility such that the amino acids in grain with a high NDF content are likely to be less available than those in grains with lower fibre values. On the other hand, the ADF content of wheat and barley, which represents the combined contents mainly of cellulose and lignin, had little influence on protein digestibility. Hemicelluloses occur both in wheat endosperm and bran (Fraser \& Holmes, 1957). Assuming a composition ( $\mathrm{g} / \mathrm{k} \mathrm{g})$ of 150 bran, 30 germ, 820 endosperm (Hinton, 1953), it can be calculated from the results of Fraser \& Holmes (1959) that there is approximately 
$50 \%$ more hemicellulose than cellulose in wheat; of the total hemicellulose, approximately $27 \%$ occurs in the endosperm and $70 \%$ in the bran; in contrast, only $5 \%$ of the total cellulose was estimated to occur in the endosperm, the majority $(89 \%)$ occurring in bran. It may be that the relatively greater content of hemicellulose, rather than cellulose, and especially the occurrence of hemicellulose in the endosperm (which contains most of the grain protein) accounts for the marked effects of hemicellulose on protein digestibility.

Previous studies such as those discussed for barley by Eggum (1973) have reported the important influence of $\mathbf{N}$ content on protein digestibility. For the results presented by Eggum \& Christensen (1975), the correlation coefficient between the content and digestibility of $\mathrm{N}$ in twenty-nine barley samples was found to be $0.57(P<0.01)$, which is similar to that found for barley in the present experiment. The correlation coefficient between hemicellulose content and $\mathbf{N}$ digestibility in barley was also of a similar magnitude but negative.

In the same way that $\mathbf{N}$ content was inversely related to fibre content for some wheats but not others, so too $\mathrm{N}$ content was inversely correlated $(P<0.05)$ with $\mathrm{N}$ digestibility for some wheats $(r-0 \cdot 35, n 47)$ but directly, though non-significantly, correlated for others $(r 0 \cdot 40, n 13)$. There appeared to be no relationship between $\mathrm{N}$ content and lysine availability in the results of Sarwar \& Bowland (1975) or Dittman et al. (1976). Similarly, an analysis of the results presented by Mohyuddin et al. (1976) for eleven wheat varieties indicated that the content and digestibility of $\mathrm{N}$ were not significantly correlated ( $r 0.48)$. Therefore, it seems that $\mathbf{N}$ content may be more closely related to protein digestibility and amino acid availability in barley than in wheat but for both grains, $\mathrm{N}$ content was a less important factor than hemicellulose content.

Whereas NDF and hemicellulose were more important factors influencing ileal protein digestibility than was ADF, for DE values determined by faecal collections, ADF, and probably cellulose levels, were more important variables than NDF.

Neither hemicellulose nor cellulose is digested by the enzymes secreted by the digestive tract, but both are susceptible to bacterial attack during fermentation. Hemicellulose has been found to be more digestible by non-ruminant species than cellulose (see Van Soest \& McQueen, 1973), and it is possible that more extensive disappearance of hemicellulose in the hind gut diminished the importance of NDF relative to ADF as a variable in faecal digestibility estimates. However, this hypothesis is not consistent with that reported by Henry (1976) who found that the hemicellulose content of pig diets was more closely associated with reductions in energy digestibility than was cellulose content.

Drennan \& Maguire (1970) and King \& Taverner (1975) determined linear relationships from which the DE content of pig diets could be predicted from their fibre content. Similar relationships have not been published for individual grains, although for poultry Salmon \& O'Neil (1977) determined prediction equations with undamanged and frost-damaged wheats in which true ME was related to crude fibre content. Moir \& Connor (1977) found that ADF, crude fibre and acid-pepsin fibre values were each related to the ME value of sorghum (Sorghum vulgare Pers.) grain for poultry. They found a linear relationship between ME and ADF in sorghum similar to that found in the present experiment between DE and ADF in wheat. There is considerable potential for the practical application of such relationships in both the pig and poultry industries.

The influence of wheat variety and locality on the composition and digestibility of wheat There have been numerous studies of the influence of variety, locality and fertilization on grain composition and, to a lesser extent, nutritive value. Woodham (1973) reviewed many such studies and concluded that location had the greatest influence on $\mathrm{N}$ content, but that variety and fertilizer treatment are also involved. Similarly in the present experiment, 
locality had a greater effect on $\mathbf{N}$ content than did variety. For example, although the average protein content of Egret was less $(P<0.01)$ than Cook, 12.1 and $14.0 \%$ respectively, the difference between grains $(P<0.001)$ from different localities was considerably greater, varying from $9 \cdot 1$ to $16.6 \%$. Although variety and locality had similar effects on the fibre content of the grains, only locality significantly influenced protein digestibility and lysine availability. Lysine availability differed between grains from different localities by as much as $4.5 \%$. On the other hand, Dittman et al. (1976) found more than $20 \%$ difference in lysine availability between wheat varieties from the Soviet Union, and Sarwar \& Bowland (1975) found approximately $10 \%$ variation in lysine availability between some Canadian wheat varieties.

\section{General discussion and conclusions}

The availability of lysine in the forty-seven wheats selected for in vitro analysis was found to vary between 0.81 and $0.9 \%$, with a mean ( $\pm \mathrm{SE}$ ) value of $0.86 \pm 0.021$. There was less variation in protein digestibility between grains, for which the mean ( $\pm \mathrm{SE})$ value was $0.92 \pm 0.011$, and the mean ( $\pm \mathrm{SE}$ ) content of truly digestible $\mathrm{N}$ was $22.6( \pm 3.60) \mathrm{mg} / \mathrm{g}$ or $12.9 \%$ truly digestible protein $(\mathrm{N} \times 5 \cdot 7)$.

Variation in nutritive value between grains is frequently ascribed to differences in the proportions of soluble-protein fractions in the grain (Sauer, 1976; Eggum, 1977). There is wide variation in the amino acid content, particularly the lysine content, of the different fractions. Generally, increases in grain protein are achieved by increasing the content of the prolamin fraction, the fraction in which the lysine content of the protein is lowest. Thus Johnson et al. (1978) and others found that although total lysine content increased as protein content increased, the proportion of lysine in the protein decreased. Nehring (1963, cited by Eggum, 1973) found that the biological value of wheat protein was inversely related to its $\mathrm{N}$ content. However, others such as March \& Biely (1973) have found little apparent relationship between nutritive value and $\mathrm{N}$ content. Clearly, the basis of such a relationship is the correlation between $\mathbf{N}$ content and contents of available amino acids, and more specifically, the content of avalable lysine, the amino acid in wheat most limiting for pig growth. In the present study, there was a significant canonical correlation $(P<0.05)$ between the content of available lysine and a canonical variate including $N$ and estimates of fibre content. N and NDF were the most important factors in the canonical variate and available lysine $(\mathrm{mg} / \mathrm{g})$ was related to $\mathrm{N}(\mathrm{mg} / \mathrm{g})$ and $\mathrm{NDF}(\mathrm{g} / \mathrm{kg})$ contents by the relationship:

available lysine $=2 \cdot 19^{* *}( \pm 0.68)+0 \cdot 11^{* * *}( \pm 0.02) \mathrm{N}-0.009 *( \pm 0.003) \mathrm{NDF}$

$$
\left(R^{2} 0.76, P<0.001\right) \text {. }
$$

There was a similar relationship when hemicellulose was included in place of $\mathrm{NDF}\left(R^{2} 0 \cdot 75\right.$, $P<0.001)$, and with ADF $(\mathrm{g} / \mathrm{kg})$ instead of NDF:

available lysine $=2.08^{*}( \pm 0.8:)+0.11^{* *}( \pm 0.03) \mathrm{N}-0.024( \pm 0.013)$ ADF

$$
\left(R^{2} 0.69, P<0.01\right) \text {. }
$$

Although only $69 \%$ of the variation in available lysine content in wheat was accounted for by $\mathrm{N}$ and $\mathrm{ADF}$ compared to $76 \%$ accounted for by $\mathrm{N}$ and NDF, in practice the relationship between available lysine content and ADF is likely to be more widely used because of the close correlation between DE content and ADF.

Therefore, in summary, of the variables of wheat composition considered in this paper, hemicellulose concentration wis most closely related to availability of lysine. Availability could be predicted from its linear relationship with various components of wheat and most simply from the linear relationship $(P<0.001)$ of lysine availability on hemicellulose 
content or NDF content. Lysine content was related to the protein content of the grain, so by including $\mathrm{N}$ content with NDF or, to a lesser extent, with ADF, linear relationships with the content of available lysine in wheat were established.

Wheat is included in diets for pigs as a source of both energy and protein, and its nutritive value is influenced both by the content of available amino acids and of available, or digestible energy. Therefore it seems that the values of the major variable of the nutritive value of wheat can be estimated from its content of $N$ and ADF.

The authors wish to thank Mrs B. Ward for assistance in the laboratory, Dr V. Bofinger for statistical advice and the Australian Pig Industry Research Committee for financial assistance.

\section{REFERENCES}

Dittman, D., Oehlke, J., Hackl, W. \& Poppe, S. (1976). Archs Tierernhärg. 26, 827.

Drennan, P. \& Maguire, M. F. (1970). Ir. J. agric. Res. 9, 197.

Eggum, B. O. (1973). Nuclear Techniques for Seed Protein Improvement. p. 391. Vienna: International Atomic Energy Agency.

Eggum, B. O. (1977). Cereal Res. Comm. 5, 153.

Eggum, B. O. \& Christensen, K. D. (1975). Breeding for Seed Protein Improvement using Nuclear Techniques, p. 135. Vienna: International Tomic Energy Agency.

Fraser, J. R. \& Holmes, D. C. (1957). J. Sci. Fd Agric. 8, 715.

Fraser, J. R. \& Holmes, D. C. (1959). J. Sci. Fd Agric. 10, 506.

Henry, Y. M. (1976). Proceedings, First International Symposium on Feed Composition, Animal Nutrient Requirements and Computerization of Diets, p. 270. Utah: Utah State University.

Hinton, J. J. C. (1953). Cereal Chem. 30, 441.

Johnson, I. L., Carpenter, K. L., Hurrell, R. F., Miller, E. L. \& Rhodes, A. P. (1978). J. Sci. Fd Agric. 29.127.

King, R. H. \& Taverner, M. R. (1975). Anim. Prod. 21, 275.

March, B. E. \& Biely, J. (1973). Can. J. Anim. Sci. 53, 569.

Mauron, J. (1970). Improving Plant Protein by Nuclear Techniques, p. 303. Vienna: International Atomic Energy Agency.

Miladi, S., Hegsted, D. M., Saunders, R. M. \& Kohler, G. O. (1972). Cereal Chem. 49. 119.

Mohyuddin, M., Sharma, T. R., Dhar, P. \& Niemann. E. G. (1976). Qual. Plant.-Pl. Fds hum. Nutr. 27.249.

Moir, K. W. \& Connor, J. K. (1977). Anim. Fd Sci. Technol. 2. 197.

Moss, H. J. \& Stenvert, N. L. (1971). Austr. J. agric. Res. 22, 547.

Nehring. K. (1963). Deutsche Akademic der Landwirtschafts - Wissenschaften. Berlin VI.

Rayner, C. J. \& Fox, M. (1976). J. Sci Fd Agric. 27, 643.

Rayner, C. J. \& Fox, M. (1978). J. agric. Fd Chem. 26, 494.

Salmon, R. E. \& O’Neil, J. B. (1977). Can. J. Anim. Sci. 57, 755.

Sarwar. G. \& Bowland, J. P. (1975). Can. J. Anim. Sci. 55, 579.

Sauer, W. C. (1976). Factors affecting amino acid availability for cereal grains and their components for growing monogastric animals. PhD Thesis. University of Manitoba, Canada.

Saunders, R. M. \& Kohler, G. O. (1972). Cereal Chem. 49, 98.

Stenvert, N. L. \& Moss, H. J. (1974). J. Sci. Fd Agric. 25, 629.

Taverner, M. R. \& Farrell, D. J. (1981). Br. J. Nutr. 46, 173.

Taverner, M. R., Hume, I. D. \& Farrell. D. J. (1981 a), Br. J. Nutr. 46. 149.

Taverner, M. R., Hume, I. D. \& Farrell, D. J. (198!b). Br. J. Nutr. 46. 159.

Van Soest. P. J. \& McQueen, R. W. (1973). Proc. Nutr. Soc. 32, 123.

Van Soest, P. J. \& Wine, R. H. (1967). J. Ass. off. agric. Chem. 50, 50.

Woodham, A. A. (1973). Qual. Plant.-Pl. Fds hum. Nutr. 23. 281. 